\title{
$J M M$

\section{PENGARUH KEPEMIMPINAN, BEBAN KERJA, DAN LINGKUNGAN KERJA TERHADAP KOMITMEN ORGANISASI PETUGAS JAGA DI LEMBAGA PEMASYARAKATAN KLAS II A MATARAM}

Oleh :

\author{
Riva Dilyanti*), Lalu Suparman**), Hermanto**)
}

\begin{abstract}
This research is aimed at (1) determining the significant effect of leadership on the organization commitment, (2) determining the significant effect of work load on the organization commitment, (3) determining the significant effect of work environment on the organizationl commitment.

The data were collected through census method. The population the research are all 57 employees working as guard in Correctional Institutions of Class II A Mataram. All of them are the respondents of this research. The analysis is using multiple regression analysis with SPSS version 17.0.

The research showed that the organization commitment of the guards is very high. This result is supported by the leadership of the head of Correctional Institutions during the well running of his functions, the work load of the guards is quite hard, and the work environment as the guards felt is very good. The statistic analysis showed that: (1) the leadership has positive and significant effect on the organization commitment. This means that the better the head of correctional institutions runs his function, the better the organization commitment of the guards and vice-versa, (2) the work load of the guards has negative and significant effect on the organization commitment. This means that the more work load of the guards, the worse the organization commitment of the guards and viceversa, (3) the work environment has positive and significant effect on the organization commitment. This means that the better the work environment for the guards, the better the organization commitment on the guards and vice-versa
\end{abstract}

Keywords : Leadership, Work Load, Work Environment, and Organization Commitment

*) Pegawai Kantor Wilayah Kementerian Hukum dan HAM Nusa Tenggara Barat

**) Dosen Program Magister Manajemen Pascasarjana Universitas Mataram

\subsection{Latar Belakang}

\section{PENDAHULUAN}

Era globalisasi memiliki pengaruh yang kuat dalam setiap aspek kehidupan sosial masyarakat, sehingga menyebabkan terjadinya berbagai perubahan sosial dalam masyarakat baik secara positif maupun negatif. Perubahan yang terjadi dalam masyarakat secara sadar atau tidak sangat mempengaruhi kehidupan suatu organisasi baik organisasi swasta maupun organisasi pemerintah dalam mencapai tujuannya. Organisai pemerintah pada dasarnya berfungsi sebagai pelayan publik diberbagai sektor kehidupan masyarakat.

Pelayanan publik oleh birokrasi merupakan salah satu perwujudan dari fungsi aparatur negara sebagai abdi masyarakat. Pelayanan publik merupakan segala kegiatan pelayanan yang dilaksanakan oleh penyelenggara pelayanan publik sebagai upaya 


\section{$J M M$

pemenuhan kebutuhan publik dan pelaksanaan ketentuan peraturan perundang-undangan (Mahmudi, 2007:213). Dalam penyelenggaraan pelayanan publik tentunya dibutuhkan perencanaan dan sistem pengawasan secara internal yang baik dan sesuai prosedur serta aturan-aturan yang berlaku. Oleh karena itu pimpinan suatu organisasi perlu melakukan pendekatan-pendekatan untuk menggerakkan, mengatur dan mengarahkan seluruh pegawai/ karyawan yang menjadinya. Unsur pimpinan perlu melakukan peninjauan atas tugas-tugas yang dibebankan kepada bawahan, berbagai kebutuhan dan permasalahan yang dihadapi para bawahan, selain itu perlu mengidentifikasi sikap dan perilaku individu terhadap tugas, agar hubungan karyawan di dalam sebuah organisasi terbentuk sikap dan perilaku yang positif, sehingga aktivitas organisasi berjalan lancar dan tujuan tercapai dengan efektif.

Pendekatan yang dilakukan oleh seorang atasan terhadap bawahan tentunya membutuhkan pola kepemimpinan yang tepat agar dapat mendorong komitmen organisasi yang dimiliki sehingga bersedia terlibat secara sungguh-sungguh dalam pencapaian tujuan organisasi. Subanegara (2005) menyatakan bahwa "kepemimpinan merupakan salah satu faktor yang dapat mempengaruhi komitmen organisasi". Sedangkan Pillai dan Williams dalam Indrayanto (2011:258), bahwa "komitmen dapat terbentuk dari adanya kepercayaan yang kuat pada diri bawahan terhadap atasannya". Dari pendapat para ahli tersebut terlihat bahwa komitmen organisasi yang dimiliki seseorang bergantung pada pola kepemimpinan yang diterapkan sehingga dapat meningkatkan usaha yang dilakukan untuk mencapai tujuan organisasi.

Hal ini juga diperkuat oleh beberapa penelitian yang telah dilakukan mengenai pengaruh kepemimpinan terhadap komitmen organisasi. Penelitian yang telah dilakukan oleh Zuraida, dkk (2013) pada pegawai PDAM Kota Magelang dimana dalam penelitiannya menunjukkan bahwa kepemimpinan berpengaruh positif dan signifikan terhadap komitmen organisasi. Hasil ini menunjukkan bahwa apabila kepemimpinan Kepala PDAM semakin baik dan akomodatis sesuai dengan harapan karyawan, maka karyawan akan mempunyai komitmen yang tinggi terhadap organisasi. Namun hasil penelitian tersebut tidak sejalan dengan hasil penelitian Ghoniyah dan Masurip (2011) yang dilakukan pada karyawan Koperasi Simpan Pinjam (KSP) Karya Niaga Kota Demak, bahwa kepemimpinan tidak berpengaruh signifikan terhadap komitmen organisasi. Hasil penelitian ini tidak signifikan karena kepemimpinan yang ada saat ini belum mampu meningkatkan komitmen organisasi para karyawan. Komitmen organisasi dapat terbangun dari individu-individu yang bersangkutan, bukan atas dasar pengaruh orang lain termasuk pimpinan.

Setiap pekerjaan yang dilakukan seseorang merupakan beban kerja baginya, bebanbeban tersebut tergantung bagaimana orang tersebut bekerja sehingga disebut sebagai beban kerja. Menurut Everly dan Girdano dalam Husain (2015:38) mengatakan bahwa beban kerja adalah keadaan di mana pekerja dihadapkan pada tugas yang harus diselesaikan pada waktu tertentu. Seseorang dengan menerima tuntutan tugas yang keras dan beban kerja yang berlebih dalam jangka panjang akan dapat menimbulkan stres kerja, kondisi stres kerja yang dialami seseorang dapat menurunkan tingkat konsentrasi dalam melaksanakan pekerjaan yang menjadi tanggung jawabnya dan hasil kerja yang kurang maksimal. Hal ini tentunya berdampak terhadap komitmen organisai yang dirasakan.

Hal ini didukung oleh penelitian yang dilakukan oleh Adityawarman, dkk., (2015) mengenai pengaruh beban kerja terhadap komitmen organisasi salah satunya dilakukan pada karyawan PT BRI (PERSERO) Tbk, Cabang Krekot, dimana hasil penelitiannya menunjukkan bahwa beban kerja berpengaruh negatif dan signifikan terhadap komitmen 


\section{$J M M$

organisasi karyawan. Seseorang yang menerima tuntutan tugas yang tinggi dapat menimbulkan kelelahan fisik dan menurunnya komitmen organisasi karyawan

Faktor organisasi lainnya yang dapat mempengaruhi komitmen organisasi seseorang adalah lingkungan kerja. Giffords (2009) dalam Hanaysha (2016 : 292) menyatakan bahwa lingkungan kerja adalah salah satu kontributor kunci dari komitmen organisasi. Lingkungan kerja merupakan salah satu pengaruh terhadap jalannya operasi perusahaan, karena lingkungan kerja adalah suatu kondisi, situasi dan keadaan yang dapat menimbulkan semangat kerja yang tinggi dalam pencapaian kinerja yang diharapkan. Manulang (2000:24). Jika karyawan menyenangi lingkungan kerja dimana dia bekerja, maka karyawan tersebut akan betah ditempat kerjanya untuk melakukan aktivitas sehingga waktu kerja dipergunakan secara efektif, hal ini menunjukkan komitmen karyawan terhadap organisainya.

Meningkatnya angka kriminalitas mengakibatkan pula meningkatnya jumlah penghuni di Lapas. Kondisi Lapas di Indonesia saat ini mengalami over kapasitas tingkat hunian mencapai 70 persen. Berdasarkan data yang ada bahwa kapasitas yang tersedia di Lapas dan Rutan seluruh provinsi hanya mampu menampung 118.961 jiwa, sedangkan jumlah tahanan dan narapidana yang ada sudah mencapai 202.682 jiwa. Kondisi tersebut juga terjadi pada beberapa Lapas dan Rutan yang ada dibawah Kantor Wilayah Kementerian Hukum dan HAM NTB, hal ini terlihat dari data yang ada. (sumber : Sistem Database Pemasyarakatan Ditjen PAS per tanggal 18 November 2016).

Tabel 1 : Jumlah penghuni dan kapasitas Lapas di Nusa Tenggara Barat

\begin{tabular}{|c|c|c|c|c|c|}
\hline \multirow{2}{*}{ NO } & \multirow{2}{*}{ UPT } & \multirow{2}{*}{$\begin{array}{l}\text { JUMLAH } \\
\text { (orang) }\end{array}$} & \multirow{2}{*}{$\begin{array}{c}\text { KAPASIT } \\
\text { AS } \\
\text { (orang) }\end{array}$} & \multicolumn{2}{|c|}{$\begin{array}{l}\text { KELEBIHAN } \\
\text { KAPASITAS }\end{array}$} \\
\hline & & & & $\begin{array}{c}\text { JUML } \\
\text { AH }\end{array}$ & $\begin{array}{l}\text { PERSENT } \\
\text { ASE }\end{array}$ \\
\hline 1 & Lapas Klas IIA Mataram & 780 & 255 & 525 & 206 \\
\hline 2 & $\begin{array}{llll}\text { Bapas } & \text { Klas } & \text { IIA Sumbawa } \\
\text { Besar } & & \end{array}$ & 352 & 250 & 102 & 41 \\
\hline 3 & Lapas Klas IIB Dompu & 264 & 148 & 116 & 78 \\
\hline 4 & $\begin{array}{l}\text { Lapas Terbuka Klas II B } \\
\text { Mataram }\end{array}$ & 13 & 57 & -- & 0 \\
\hline 5 & LPKA Klas II Mataram & 42 & 72 & -- & 0 \\
\hline 6 & Rutan Klas IIB Praya & 242 & 92 & 150 & 163 \\
\hline 7 & Rutan Klas IIB Raba Bima & 240 & 135 & 105 & 78 \\
\hline 8 & Rutan Klas IIB Selong & 236 & 93 & 143 & 154 \\
\hline
\end{tabular}

Sumber : Sistem Database Pemasyarakatan (SDP) Kanwil Kemenkumham NTB, 2016

Lapas dan Rutan yang ada di wilayah Nusa Tenggara Barat memperlihatkan kondisi yang tidak jauh berbeda dengan wilayah lainnya di Indonesia. Terjadinya kelebihan kapasitas tingkat hunian mencapai 97 persen diatas kapasitas hunian yang tersedia, termasuk Lapas Kelas II A Mataram. Kelebihan kapasitas tingkat hunian Lapas Mataram mencapai 206 persen. Sedangkan jika dilihat dari sisi ketersediaan sumber daya manusia yang ada, bahwa jumlah petugas Lapas Mataram yang minim, nampak sangat tidak seimbang dengan jumlah penghuni. Petugas jaga yang tersedia berjumlah 57 orang, 


\section{$J M M$

yang dibagi menjadi 4 regu jaga dan masing - masing regu berjumlah 14 orang. Kebutuhan minimum petugas jaga ialah 20 orang per shift untuk menjaga dengan kapasitas normal. Berdasarkan data terlihat bahwa rasio jumlah petugas dan penghuni Lapas Mataram tak sebanding, karena masih jauh dari standar minimum yang telah ditetapkan.

Dalam menjalankan fungsinya Petugas Jaga Lapas tentunya membutuhkan suasana kerja yang aman dan nyaman karena mereka bidang tugasnya berhadapan langsung dengan narapidana, hubungan kerja yang harmonis antara sesama petugas. Selain itu mereka membutuhkan fasilitas kerja yang memadai, seperti HT, CCTV, alat detektor narkoba, fasilitas jammer/ pengacak signal handphone, tersedianya wartel di dalam Lapas, persenjataan yang memadai baik dari segi kuantitas maupun kualitas, dan alat/ tabung pemadam kebakaran yang memadai serta kondisi dan jumlah blok hunian tahanan dan narapidana yang layak dan memadai.

Berdasarkan uraian fenomena yang terjadi dan dari beberapa teori yang dikemukakan para ahli serta hasil penelitian empiris, peneliti tertarik untuk melakukan studi tentang pengaruh kepemimpinan, beban kerja, dan lingkungan kerja, terhadap komitmen organisasi petugas jaga di Lapas Klas II A Mataram.

\subsection{Tujuan Penelitian}

Tujuan dari penelitian ini adalah : (1) Untuk menganalisis dan mengetahui signifikansi pengaruh dari kepemimpinan terhadap komitmenn organisasi petugas jaga di Lapas Klas II A Mataram. (2) Untuk menganalisis dan mengetahui signifikansi pengaruh dari beban kerja terhadap komitmen organisasi petugas jaga di Lapas Klas II A Mataram. (3) Untuk menganalisis dan mengetahui signifikasi pengaruh dari lingkungan kerja terhadap komitmen organisasi petugas jaga di Lapas Klas II A Mataram

\subsection{Studi Komitmen Organisasi}

\section{STUDI PUSTAKA}

\subsubsection{Pengertian Komitmen Organisasi}

Robbins dan Judge (2008:100) menyatakan komitmen organisasi adalah sesuatu keadaan yang menunjukkan adanya keterlibatan psikologis seorang individu pada suatu organisasi tertentu. Di mana individu tersebut memihak, loyal dan terlibat dalam organisasi tersebut. Dengan kata lain, komitmen organisasi adalah kekuatan relatif dari keterlibatan individu dengan organisasi dalam mencapai tujuan dan nilai-nilai yang ditetapkan. Lebih lanjut dikatakan bahwa Komitmen organisasi (organization commitment), didefinisikan sebagai suatu keadaan dimana seseorang karyawan memihak organisasi tertentu serta tujuan-tujuan dan keinginannya untuk mempertahankan keanggotaan dalam organisasi tersebut. Jadi, keterlibatan pekerjaan yang tinggi berarti memihak pada pekerjaan tertentu seseorang individu, sementara komitmen organisasional yang tinggi berarti memihak organisasi yang merekrut individu tersebut.

Komitmen organisasi menurut Ivancevich (2006:234) adalah perasaan identifikasi, keterlibatan, dan kesetiaan yang diekspresikan oleh karyawan terhadap perusahaan. Berdasarkan pengertian tersebut dapat diidentifikasi bahwa komitmen terhadap organisasi melibatkan tiga sikap yaitu, rasa identifikasi dengan tujuan organisasi, perasaan terlibat dalam tugas-tugas organisasi, dan perasaan setia terhadap organisasi. Bukti penelitian menunjukkan bahwa tidak adanya komitmen organisasi dapat mengurangi efektivitas organisasi. 


\section{$J M M$

\subsubsection{Dimensi Komitmen Organisasional}

Porter, dkk. (dalam Miner, 1992 :124) menyatakan bahwa komitmen organisasi sebagai kekuatan yang bersifat relatif dari individu dalam mengidentifikasi keterlibatan dirinya ke dalam bagian organisasi). Sikap ini ditandai oleh tiga hal, yaitu : 1) Kepercayaan yang kuat dan penerimaan terhadap nilai-nilai dan tujuan organisasi; 2) Kesediaan untuk sungguh-sungguh berusaha atas nama organisasi; dan 3) Keinginan yang kuat untuk mempertahankan keanggotaan di dalam organisasi. Menurut Amstrong (1992 : 183) ada tiga hal yang dipandang dapat mempengaruhi komitmen organisasi, yaitu : 1) rasa memiliki terhadap organisasi, 2) rasa senang terhadap pekerjaan, dan 3) kepercayaan pada organisasi.

Tiga dimensi terpisah dari komitmen organisasioanal yang diutarakan oleh Robbins dan Judge, (2008:101) adalah :

1) Komitmen afektif (Affectif Commitment) merupakan perasaan emosional untuk organisasi dan keyakinan dalam nilai-nilainya.

2) Komitmen berkelanjut (continuance comimitment) adalah nilai ekonomi yang dirasa dari bertahan dalam suatu organisasi bila dibandingkan dengan meninggalkan organisasi tersebut. Seorang karyawan mungkin akan berkomitmen kepada seorang pemberi kerja karena ia di bayar tinggi dan merasa bahwa pengunduran diri dari perusahaan akan menghancurkan keluarganya.

3) Komitmen normatif (normative commitment) adalah kewajiban untuk bertahan dalam organisasi untuk alasan-alasan moral atau etis. Sebagai contoh, seorang karyawan yang memelopori sebuah inisatif baru mungkin bertahan dengan seorang pemberi kerja karena ia merasa "meninggalkan seseorang dalam keadaan yang sulit" bila ia pergi.

\subsection{Studi Kepemimpinan}

\subsubsection{Pengertian Kepemimpinan}

Robbins (2006:432) menyatakan Kepemimpinan adalah kemampuan untuk mempengaruhi kelompok menuju pencapaian sasaran. Kartono (2005:153) menyatakan mepemimpinan adalah kemampuan untuk memberikan pengaruh yang konstruktif kepada orang lain untuk melakukan suatu usaha kooperatif mencapai tujuan yang sudah direncanakan. Rivai (2003:65) menyatakan kepemimpinan adalah peranan dan juga suatu proses untuk mempengaruhi orang lain.

Northouse (2003:3) Kepemimpinan adalah suatu proses dimana individu mempengaruhi kelompok untuk mencapai tujuan. Pengertian ini dipertajam oleh Dubrin (2001:3) bahwa kepemimpinan itu adalah kemampuan untuk menanamkan keyakinan dan memperoleh dukungan dari anggota organisasi untuk mencapai tujuan organisasi.

Dubrin (2005:3) mengemukakan bahwa kepemimpinan itu adalah upaya mempengaruhi banyak orang melalui komunikasi untuk mencapai tujuan, cara mempengaruhi orang dengan petunjuk atau perintah, tindakan yang menyebabkan orang lain bertindak atau merespons dan menimbulkan perubahan positif, kekuatan dinamis penting yang memotivasi dan mengkoordinasikan organisasi dalam rangka mencapai tujuan, kemampuan untuk menciptakan rasa percaya diri dan dukungan diantara bawahan agar tujuan organisasi dapat tercapai.

\subsubsection{Fungsi Kepemimpinan}

Nawawi (2001:141-151), Rivai (2003:50-53), dan Antonio (2007:20) telah menguraikan fungsi-fungsi kepemimpinan, yang dijalankan dalam proses kepemimpinan. Interaksi 


\section{$J M M$

sosial yang terjadi antara pemimpin dan pengikut (bawahan) dalam suatu kelompok atau organisasi untuk membentuk kebersamaan pandangan, harapan dan tujuan yang ingin dicapai. Proses kepemimpinan merupakan gejala sosial, yang berlangsung dalam situasi sosial tertentu, yang dapat berubah sewaktu-waktu, dan pemimpin berupaya membuat situasi sosial yang dapat mendukung adanya kebersamaan.

Dalam menjalankan fungsi kepemimpinan dimensi yang perlu diperhatikan adalah :

a. Tingkat kemampuan pemimpin mengarahkan (direction) pengikut (bawahan) yang nampak dari responnya dalam kebersamaan.

b. Tingkat dukungan (suport) pengikut (baawahan), yang ditunjukan melalui kemauan dan kemampuan serta dari keiikutsertaan atau keterlibatan mereka dalam melaksanakan tugas-tugas organisasi.

Berdasarkan kedua dimensi tersebut, maka Nawawi (2001:141-151) dan Rivai (2003:50-

53) telah menguraikan fungsi-fungsi pokok kepemimpinan berikut :

1) Fungsi instruktif. Pemimpin menentukan dan memutuskan apa, bagaimana, bilamana, dimana, tugas/pekerjaan dilaksanakan dan menentukan siapa bawahan/pengikut untuk melaksanakan tugas.

2) Fungsi konsultatif. Pemimpin dan bawahan/ pengikut memiliki tugas masing-masing sesuai yang digariskan organisasi. Dalam menjalankan tugas, mereka membutuhkan masukan, petunjuk, saran, pendapat dari dan utnuk mereka.

3) Fungsi delegasi. Fungsi ini dijalankan dalam upaya mendistribusikan atau membagi kewenangan yang diemban pemimpin, karena setiap pemimpin tidak mungkin bekerja sendiri melaksanakan tugas pokok organisasinya; sehingga ia harus melimpahkan sebagian wewengangnya kepada staf yang membantunya atau bawahannya.

4) Fungsi partisipasi; pemimpin harus berusaha mengaktifkan para bawahannya/ pengikutnya, baik dalam keiktusertaan mengambil keputusan maupun dalam melaksanakan tugas pokoknya sesuai dengan posisi/ jabatan dan wewenangnya masing-masing.

5) Fungsi pengendalian; ini dapat dilaksanakan melalui kegiatan pengawasan dan merupakan cara yang paling efektif. Selain itu pengendalian dilakukan melalui kegiatan pengarahan, koordinasi dan bimbingan.

\subsection{Studi Beban Kerja}

\subsubsection{Pengertian Beban Kerja}

Beberapa ahli menyebutkan bahwa beban kerja tidak hanya menyangkut pekerjaan yang dipandang berat, tetapi juga pekerjaan yang ringan. Seperti yang dikemukakan Schultz (Suwatno, 2011:250) bahwa beban kerja ditempat kerja bukan saja menyangkut kelebihan pekerjaan (work overload) tetapi termsuk pula yang setara/sama atau sebaliknya kekurangan atau terlalu rendah/kecil pekerjaan (work underload)

Pengertian beban kerja menurut Suwatno (2003) adalah sejumlah kegiatan yang harus diselesaikan oleh suatu unit organisasi atau pemegang jabatan secara sistematis dengan menggunakan teknik analisis jabatan, teknik analisa beban kerja, atau teknik manajemen lainnya dalam jangka waktu tertentu untuk mendapatkan informasi tentang efisiensi dan efektivitas kerja suatu unit organisasi.

Menurut Permendagri No. 12 tahun 2008, yang dimaksud dengan beban kerja adalah besaran pekerjaan yang harus dipikul oleh jabatan atau unit organisasi yang merupakan hasil kali antara volume kerja dan norma waktu, dimana perhitungan analisa beban kerjanya dengan mempertimbangkan faktor-faktor jam kerja, waktu kerja, latar belakang pendidikan pegawai, dan jenis pekerjaan. Beban kerja merupakan sekumpulan 


\section{$J M M$

atau sejumlah kegiatan yang harus diselesaikan oleh suatu unit organisasi atau pemegang jabatan yang dilakukan secara sitematis dengan menggunakan teknik analisis jabatan, teknik analisis beban kerja atau teknik manajemen lainnya.

\subsubsection{Dampak Beban Kerja}

Beban kerja yang berlebih dapat menyebabkan benturan-benturan atau tekanantekanan yang terjadi pada dirinya yang dapat menimbulkan stress bagi karyawan. Hal tersebut sesuai dengan penelitian yang dilakukan oleh Hauck et al., (2008) menyatakan bahwa penumpukan beban kerja akan mengakibatkan penurunan pada kinerja dan meningkatkan stress kerja. Menurut Kirckcaldy et al., (2000) dalam Wijono (2006 : 46) akibat dari beban kerja yang berlebih adalah produktivitas kerja menjadi turun, maka perusahaan harus terus berupaya memotivasi karyawan untuk dapat mengatasi tekanantekanan tersebut sehingga tidak menjadi masalah dalam internal perusahaan yang akan menghambat kinerja karyawan.

Dampak negatif dari kelebihan beban kerja menurut Winaya (2000:45), beban kerja yang tidak sesuai dengan kemampuan tenaga kerja dapat menimbulkan dampak negatif bagi petugas, yaitu :

a) Kualitas kerja menurun; beban kerja yang terlalu berat tidak diimbangi dengan kemampuan tenaga kerja, kelebihan beban kerja akan mengakibatkan menurunnya kualitas kerja akibat dari kelelahan fisik dan turunnya konsentrasi, pengawasan diri, akurasi kerja sehingga hasil kerja tidak sesuai dengan standar.

b) Keluhan pelanggan; keluhan pelanggan timbul karena hasil kerja yaitu karena pelayanan yang diterima tidak sesuai dengan harapan seperti harus menunggu lama, hasil layanan yang tidak memuaskan.

c) Kenaikan tingkat absensi; beban kerja yang terlalu banyak bisa juga mengakibatkan petugas terlalu lelah atau sakit. Hal ini akan berakibat buruk bagi kelancaran kerja organisasi karena tingkat absensi terlalu tinggi, sehingga dapat mempengaruhi terhadap kinerja organisasi secara keseluruhan.

\subsection{Studi Lingkungan Kerja}

\subsubsection{Pengertian Lingkungan Kerja}

Menurut Nitisemito (1996:109) menyatakan bahwa lingkungan kerja adalah segala sesuatu yang berada disekitar pekerja yang dapat mempengaruhi individu dalam menjalankan tugas-tugas yang dibebankan. Selanjutnya Mangkunegara (2009:17) mengatakan bahwa faktor lingkungan kerja organisasi sangat menunjang bagi individu dalam mencapai prestasi kerja. Faktor lingkungan organisasi yang dimaksud antara lain uraian jabatan yang jelas, otoritas yang memadai, target kerja yang menantang, pola komunikasi kerja efektif, hubungan kerja yang harmonis, iklim kerja respek dan dinamis, peluang berkarier dan fasilitas kerja yang memadai.

Menurut Moekijat (2002 : 1) secara sederhana yang dimaksud dengan fasilitas adalah suatu sarana fisik yang dapat memproses suatu masukan (input) menuju keluaran (output) yang diinginkan. Selanjutnya menurut Buchari (2001) fasilitas adalah penyedia perlengkapan-perlengkapan fisik untuk memberikan kemudahan kepada penggunanya, sehingga kebutuhan-kebutuhan dari pengguna fasilitas tersebut dapat terpenuhi. Fasilitas kerja merupakan sarana yang diberikan perusahaan untuk mendukung jalannya roda perusahaan dalam mencapai tujuan yang ditetapkan oleh pemegang kendali. 


\section{$J M M$

\subsubsection{Indikator-indikator Lingkungan Kerja}

Terdapat beberapa indikator untuk menilai lingkungan kerja. Menurut Sedarmayanti (2011:28) yang menjadi indikator-indikator lingkungan kerja adalah penerangan/cahaya ditempat kerja, temperatur/suhu udara ditempat kerja, kelembaban ditempat kerja, sirkulasi udara ditempat kerja, kebisingan ditempat kerja, getaran mekanis ditempat kerja, bau tidak sedap ditempat kerja, tata warna ditempat kerja, dekorasi ditempat kerja, music ditempat kerja, keamanan ditempat kerja, hubungan sesama rekan kerja dan hubungan kerja antara atasan dana bawahan.

Sedangkan Nitisemito (1996:159) menyatakan bahwa lingkungan kerja diukur melalui indikator sebagai berikut:

a. Suasana kerja; Setiap karyawan selalu menginginkan suasana kerja yang menyenangkan, suasana kerja yang nyaman itu meliputi cahaya/ penerangan yang jelas, suara yang tidak bsising dan tenang, kemanan dalam bekerja

b. Hubungan dengan rekan kerja; maksudnya hubungan dengan rekan kerja harmonis dan tanpa ada saling intrik diantara sesama rekan kerja. Salah satu faktor yang dapat mempengaruhi karyawan tetap tinggal dalam suatu organisasi adalah adanya hubungan kerja yang harmonis antara rekan kerja. Hubungan rekan kerja yang harmonis dan kekeluargaan merupakan salah satu factor yang dapat mempengaruhi seseorang.

c. Tersedianya fasilitas kerja; maksudnya bahwa peralatan yang digunakan untuk mendukung kelancaran kerja lengkap/mutakhir.

\subsection{Kerangka Konseptual}

Berdasarlkan fenomena, penelitian terdahulu dan landasan teori sebelumnya, maka disusun kerangka konseptual sebagai berikut :

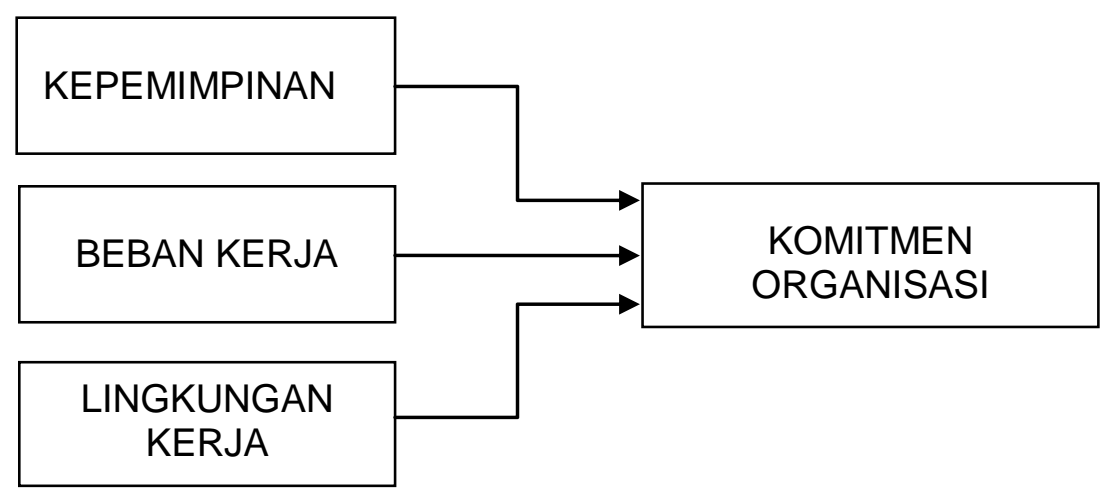

Gambar 1 : Kerangka Konseptual Penelitian

\subsection{Hipotesis Penelitian}

Berdasarkan tujuan penelitian, tinjauan hasil penelitian empiris, studi teori dan kerangka konseptual di atas, maka hipotesis penelitian dapat dirumuskan sebagai berikut :

1) Diduga bahwa kepemimpinan berpengaruh positif dan signifikan terhadap komitmen organisasi petugas jaga Lapas di Lapas Klas II A Mataram

2) Diduga bahwa beban kerja berpengaruh negatif dan signifikan terhadap komitmen organisasi petugas jaga Lapas di Lapas Klas II A Mataram 


\section{$J M M$

\subsection{Rancangan Penelitian}

\section{METODE PENELITIAN}

Berdasarkan tujuan penelitian yang ingin dicapai, peneliti menggunakan penelitian asosiatif, dengan bentuk analisisnya adalah kausalitas, karena peneliti menganalisis secara mendalam hubungan antar variabel atau pengaruh variabel independen yakni kepemimpinan, beban kerja, dan lingkungan kerja terhadap variabel dependen yakni komitmen organisasi. Subjek penelitian adalah petugas jaga di Lapas Klas II A Mataram di bawah Kantor Wilayah Kementerian Hukum dan HAM Nusa Tenggara Barat.

\subsection{Metode Pengumpulan Data}

Metode pengumpulan data yang digunakan dalam penelitian ini untuk memperoleh data/ informasi yang dibutuhkan adalah metode sensus. Populasi dalam penelitian ini dalah seluruh pegawai yang berstatus sebagai petugas jaga Lapas Klas II A Mataram. Jumlah anggota populasi sebanyak 57 orang. Seluruh anggota populasi dijadikan responden. Teknik pengumpulan data yang digunakan dalam penelitian ini adalah teknik angket, wawancara dan dokumentasi. Angket yang disebarkan berisi kuesioner yang telah disusun berdasarkan indikator masing-masing variabel. Wawancara diperlukan oleh peneliti untuk mendapatkan gambaran secara jelas tentang peristiwa, waktu dan ruang (tempat), pelaku, kegiatan, objek, perbuatan, kejadian lainnya. Dokumentasi dilakukan untuk mendapatkan data tentang petugas jaga lapas Klas II A Mataram, hasil-hasil penelitian dan literatur yang relevan.

\subsection{Definisi Operasional Variabel}

\section{1). Variabel Komitmen Organisasi (Y)}

Komitmen organisasi adalah tanggapan responden atas sikap dan perilaku yang dimiliki sehubungan dengan keterlibatannya sebagai petugas jaga Lapas Klas II A Mataram, yang ditandai dengan kepercayaan dan penerimaan yang kuat atas tujuan dan nilai-nilai organisasi, kemauan untuk mengusahakan tercapainya kepentingan organisasi, keinginan yang kuat untuk mempertahankan kedudukan sebagai anggota organisasi.

Dimensi dan indikator variabel sebagai berikut : Pertama dimensi komitmen afektif (affectif commitment) merupakan tanggapan petugas jaga Lapas atas kepercayaan dan penerimaan terhadap tujuan dan nilai-nilai yang dilihat dari : (1) kebahagiaan menghabiskan karir, (2) persoalan organisasi juga persoalan karyawan, (3) rasa memiliki yang kuat, (4) terikat secara emosional, (5) menjadi bagian keluarga organisasi, (6) organisasi sangat berarti. Kedua dimensi komitmen berkelanjutan (continuance commitment) merupakan tanggapan petugas jaga Lapas atas kemauan untuk menggunakan usaha yang sungguh-sungguh guna kepentingan organisasi, yang dilihat dari : (7) kesulitan meninggalkan organisasi, (8) kerterbatasan alternative pekerjaan, (9) tetap tinggal di organisasi adalah kebutuhan, (10) sedikit pilihan untuk dipertimbangkan, (11) terlalu banyak pengorbanan diri, (12) banyak kehidupan yang akan terganggu. Ketiga dimensi komitmen normatif (normative commitment) merupakan tanggapan petugas jaga Lapas atas keinginan untuk memelihara keanggotaan dala organisasi, yang dilihat dari : (13) kewajiban tetap bersama atasan, (14) tidak tepat meninggalkan organisasi, (15) bersalah apabila meninggalkan organisasi, (16) loyal pada organisasi, (17) tanggung jawab yang tinggi, (18) berhutang budi pada organisasi.

\section{2). Variabel Kepemimpinan (X1)}

Yang dimaksud dalam penelitian ini adalah tanggapan petugas jaga Lapas terhadap 


\section{$J M M$

sikap dan perilaku Kepala Lapas dalam menjalankan fungsi-fungsi kepemimpinan seperti : menyampaikan visi, misi, tujuan dan program kerja, mendistribusikan tugas pekerjaan kepada bawahan, memberikan perintah dan arahan menjalankan tugasau kegiatan, memberikan motivasi dan penghargaan kepada bawahan, melakukan pengawasan dan pengendalian atas seluruh kegiatan organisasi.

Untuk mendapatkan informasi atau data tentang semua indikator tersebut di atas, peneliti menggunakan daftar pertanyaan atau pernyataan (quesioner). Tipe data yang dijaring berbentuk skala likert dengan 5 point, yakni skore $1=$ tidak setuju, skore $2=$ kurang setuju, skore $3=$ agak setuju, skore $4=$ setuju dan skore $5=$ sangat setuju.

\subsection{Variabel Beban Kerja (X2)}

Beban kerja merupakan tanggapan petugas jaga Lapas mengenai tugas yang diberikan dan harus diselesaikan dalam waktu yang telah ditentukan. Indikator yang digunakan adalah : (1) Lamanya atau banyaknya waktu kerja menunjukkan rentang waktu penyelesaian tugas penjagaan, (2) tingkat kesulitan pekerjaan atau resiko tugas penjagaan, (3) kesesuaian aturan/ standar operasional prosedur (SOP) tugas-tugas penjagaan dengan pekerjaan di lapangan (4) Jumlah Pekerjaan menunjukkan banyak atau sedikitnya volume tugas jaga yang diberikan, dan (5) besarnya tanggung jawab terhadap tugas penjagaan.

Untuk mendapatkan informasi atau data tentang semua indikator tersebut di atas, peneliti menggunakan daftar pertanyaan atau pernyataan (quesioner). Tipe data yang dijaring berbentuk skala likert dengan 5 point, yakni skore $1=$ tidak setuju, skore $2=$ kurang setuju, skore $3=$ agak setuju, skore $4=$ setuju dan skore $5=$ sangat setuju.

\subsection{Variabel Lingkungan Kerja (X3)}

Lingkungan kerja merupakan tanggapan responden petugas jaga Lapas terhadap unsur-unsur yang terdapat disekitar Lapas yang dapat mempengaruhi petugas jaga melaksanakan pekerjaannya di Lembaga Pemasyarakatan Klas II A Mataram.

Untuk mendapatkan informasi atau data tentang semua indikator tersebut di atas, peneliti menggunakan daftar pertanyaan atau pernyataan (quesioner). Tipe data yang dijaring berbentuk skala likert dengan 5 point, yakni skore $1=$ tidak setuju, skore $2=$ kurang setuju, skore $3=$ agak setuju, skore $4=$ setuju dan skore $5=$ sangat setuju.

\subsection{Teknik analisis}

1). Analisis deskriptif; dimaksudkan untuk memberi gambaran tentang variabel yang dikaji, seperti komitmen organisasi para pegawai petugas jaga Lapas Klas II A Mataram, kepemimpinan kepala Lapas Klas II A Mataram, Beban kerja yang dirasakan para petugas jaga Lapas, dan lingkungan kerja terutama yang berkaitan dengan tugas para petugas jaga Lapas.

Nilai/skor rata-rata dari masing-masing variabel (indikator/item indikator), baik untuk kepemimpinan, beban kerja, lingkungan kerja dan komitmen organisasi, dapat dikelompokkan dalam kelas interval dengan jumlah kelas $=5$. Interval kelas dihitung dengan rumus :

$$
\text { Interval }=\frac{\text { nilai tertinggi }- \text { nilai terendah }}{\text { jumlah kelas }}
$$

Pada penelitian ini memiliki interval $=0.8$, hasil ini didapat dari :

$$
\text { Interval }=\frac{5-1}{5}=0,8
$$




\section{$J M M$ UNRAM

Dari hasil perhitungan tersebut, dapat dibuat skala distribusi kriteria skor dalam bentuk interval sebagaimana terlihat pada Tabel 2

Tabel 2 : Konversi nilai skor skala Likert sebagai kriteria dari masing-masing sifat dan kategori variabel

\begin{tabular}{|c|l|l|l|l|}
\hline \multirow{2}{*}{$\begin{array}{c}\text { Kriteria } \\
\text { Skore }\end{array}$} & $\begin{array}{c}\text { Komitmen } \\
\text { Organisasi }\end{array}$ & $\begin{array}{c}\text { Kepemim- } \\
\text { pinan }\end{array}$ & $\begin{array}{c}\text { Beban } \\
\text { Kerja }\end{array}$ & $\begin{array}{c}\text { Lingkungan } \\
\text { Kerja }\end{array}$ \\
\cline { 2 - 5 }$\geq 4,20$ & Sangat Tinggi & Sangat Baik & Sangat Puas & $\begin{array}{l}\text { Sangat } \\
\text { Tinggi }\end{array}$ \\
\hline $3,40-4,19$ & Tinggi & Baik & Puas & Tinggi \\
\hline $2,60-3,39$ & Cukup/Sedang & Cukup Baik & Cukup Puas & Sedang \\
\hline $1,80-2,59$ & Agak rendah & $\begin{array}{l}\text { Kurang } \\
\text { Baik }\end{array}$ & $\begin{array}{l}\text { Kurang } \\
\text { Puas }\end{array}$ & Rendah \\
\hline$\leq 1,79$ & Sangat rendah & Tidak baik & Tidak Puas & $\begin{array}{l}\text { Sangat } \\
\text { Rendah }\end{array}$ \\
\hline
\end{tabular}

\section{2). Analisis Regresi Berganda}

Untuk menguji hipotesis yang telah diajukan sebelumnya, maka digunakan alat analisis regresi berganda sebagai berikut (Sugiyono, 2016: 275;):

Keterangan :

$$
Y=a+b_{1} X_{1}+b_{2} X_{2}+b_{3} X_{3}+e
$$

Y : Komitmen Organisasi

$\mathrm{X}_{1}$ : Kepemimpinan

$\mathrm{X}_{2} \quad$ : Beban Kerja

$X_{3}$ : Lingkungan Kerja

$$
\begin{array}{ll}
a & : \text { Konstanta } \\
b_{1} & : \text { Koefisien regresi kepemimpinan } \\
b_{2} & : \text { Koefisien regresi beban kerja } \\
b_{3} & : \text { Koefisien regresi lingkungan kerja } \\
\text { e } & : \text { Error }
\end{array}
$$

\section{1) Hasil Uji Validitas Instrumen Penelitian}

Hasil uji validitas dan reliabilitas kuisioner penelitian untuk keempat variabel sebagaimana terlihat pada Tabel 3. Nampak bahwa nilai $r$ hitung untuk masing-masing instrumen keempat variabel apabila dibandingkan dengan nilai $r$ tabel lebih dari 0,3, maka dapat disimpulkan bahwa masing-masing instrumen dinyatakan valid.

\section{Tabel 3. Validitas Instrumen Penelitian}

\section{Koefisien Korelasi Instrumen Penelitian}

\begin{tabular}{l|c|c|c}
$\begin{array}{l}\text { Komitmen } \\
\text { Organisasi }\end{array}$ & Kepemimpinan & Beban Kerja & $\begin{array}{c}\text { Lingkungan } \\
\text { Kerja }\end{array}$ \\
\hline
\end{tabular}




\section{$J M M$ UNRAM

\begin{tabular}{|c|c|c|c|c|c|c|c|}
\hline Item & r hitung & Item & r hitung & Item & r hitung & Item & r hitung \\
\hline 1 & 0,515 & 1 & 0,761 & 1 & 0,715 & 1 & 0,552 \\
\hline 2 & 0,566 & 2 & 0,707 & 2 & 0,651 & 2 & 0,552 \\
\hline 3 & 0,593 & 3 & 0,565 & 3 & 0,712 & 3 & 0,369 \\
\hline 4 & 0,562 & 4 & 0,690 & 4 & 0,443 & 4 & 0,516 \\
\hline 5 & 0,562 & 5 & 0,634 & 5 & 0,715 & 5 & 0,609 \\
\hline 6 & 0,548 & 6 & 0,648 & & & 6 & 0,550 \\
\hline 7 & 0,399 & 7 & 0,743 & & & 7 & 0,735 \\
\hline 8 & 0,628 & 8 & 0,718 & & & 8 & 0,450 \\
\hline 9 & 0,669 & 9 & 0,367 & & & 9 & 0,550 \\
\hline 10 & 0,563 & 10 & 0,761 & & & 10 & 0,516 \\
\hline 11 & 0,464 & 11 & 0,743 & & & 11 & 0,725 \\
\hline 12 & 0,723 & 12 & 0,632 & & & & \\
\hline 13 & 0,623 & & & & & & \\
\hline 14 & 0,620 & & & & & & \\
\hline 15 & 0,524 & & & & & & \\
\hline 16 & 0,604 & & & & & & \\
\hline 17 & 0,566 & & & & & & \\
\hline 18 & 0,668 & & & & & & \\
\hline
\end{tabular}

Sumber : Data primer diolah

\section{2). Hasil Uji Reliabilitas Instrumen Penelitian}

Hasil uji reabilitas instrumen penelitian untuk keempat variabel yang diteliti sebagaimana terlihat pada Tabel 4. Nampak bahwa nilai cronbach's alpha untuk masingmasing instrumen variabel Komitmen Organisasi, Kepemimpinan, Beban Kerja, dan Lingkungan Kerja lebih besar dari 0,60 sehingga dapat disimpulkan bahwa masingmasing instrumen penelitian adalah reliable atau dapat diandalkan.

Tabel 4. Hasil Uji Reliabilitas Variabel Penelitian

\begin{tabular}{|c|l|c|c|}
\hline No. & Indikator Beban Kerja & $\begin{array}{c}\text { Cronbach's } \\
\text { Alpha }\end{array}$ & Kriteria \\
\hline 1. & Komitmen Organisasi & 0,913 & reliabel \\
\hline 2. & Kepemimpinan & 0,918 & reliabel \\
\hline 3. & Beban Kerja & 0,847 & reliabel \\
\hline 4. & Lingkungan Kerja & 0,864 & reliabel \\
\hline
\end{tabular}

Sumber : Data primer diolah 


\section{$J M M$ UNRAM

\section{HASIL PENELITIAN DAN PEMBAHASAN}

\subsection{Deskripsi Variabel Penelitian}

\section{1). Komitmen Organisasi}

Komitmen organisasi adalah tanggapan responden atas sikap dan perilaku yang dimiliki sehubungan dengan keterlibatannya sebagai petugas jaga Lapas Klas II A Mataram, yang ditandai dengan kepercayaan dan penerimaan yang kuat atas tujuan dan nilai-nilai organisasi, kemauan untuk mengusahakan tercapainya kepentingan organisasi, keinginan yang kuat untuk mempertahankan kedudukan, dengan indikator komitmen afektif, komitmen berkelanjutan, dan komitmen normatif Kategori tanggapan penilaian terhadap masing-masing item komitmen organisasi terlihat pada Tabel 5. sebagai berikut :

Tabel 5. Nilai Skor Rata-Rata dan Kategori Indikator Komitmen Organisasi (Y)

\begin{tabular}{|l|l|c|c|}
\hline No & \multicolumn{1}{|c|}{ Indikator } & $\begin{array}{c}\text { Nilai } \\
\text { Skor }\end{array}$ & Kategori \\
\hline 1. & Kebahagiaan berkarir dalam organisasi & 4,40 & Sangat Tinggi \\
\hline 2. & Persoalan organisasi sebagai persoalan diri & 4,35 & Sangat Tinggi \\
\hline 3. & Rasa memiliki yang kuat pada organisasi & 4,42 & Sangat Tinggi \\
\hline 4. & Ikatan secara emosional terhadap organisasi & 4,28 & Sangat Tinggi \\
\hline 5. & Merasa menjadi bagian keluarga organisasi & 4,32 & Sangat Tinggi \\
\hline 6. & Merasa bahwa organisasinya sangat berarti & 4,39 & Sangat Tinggi \\
\hline 7. & Resiko meninggalkan organisasi & 4,09 & Tinggi \\
\hline 8. & Kekhawatiran jika berhenti dari organisasi & 4,23 & Sangat Tinggi \\
\hline 9. & $\begin{array}{l}\text { Tetap tinggal dalam organisasi jadi } \\
\text { kebutuhan }\end{array}$ & 4,30 & Sangat Tinggi \\
\hline 10. & $\begin{array}{l}\text { Sedikit pilihan untuk meninggalkan } \\
\text { organisasi }\end{array}$ & 4,37 & Sangat Tinggi \\
\hline 11. & $\begin{array}{l}\text { Merasa banyak pengorbanan untuk } \\
\text { organisasi }\end{array}$ & 4,61 & Sangat Tinggi \\
\hline 12. & $\begin{array}{l}\text { Kehidupan terganggu, meninggalkan } \\
\text { organisasi. }\end{array}$ & 4,30 & Sangat Tinggi \\
\hline 13. & $\begin{array}{l}\text { Adanya kewajiban untuk tetap bersama } \\
\text { atasan }\end{array}$ & 4,16 & Tinggi \\
\hline 14. & Merasa tidak akan meninggalkan organisasi, & 4,25 & Sangat Tinggi \\
\hline 15. & Merasa bersalah meninggalkan organisasi & 4,47 & Sangat Tinggi \\
\hline & \multicolumn{1}{|c|}{ Tangat } \\
\hline
\end{tabular}

Sumber : Data Primer Diolah

\section{2). Kepemimpinan}




\section{$J M M$

Kepemimpinan adalah persepsi responden terhadap sikap dan perilaku Kepala Lapas dalam menjalankan fungsi-fungsi kepemimpinan seperti : menyampaikan visi, misi yang hendak dicapai, menyampaikan tujuan dan program kerja yang harus dijalankan, membagi tugas secara adil dan tidak diskriminatif, membagi tugas berdasarkan kompetensi, memberikan perintah dan pengarahan yang mengandung nilai kebenaran, memberikan perintah dengan cara yang jelas dan tegas, memberikan motivasi dan penghargaan kepada bawahan, mendistribusikan sumber daya keuangan secara adil dan merata, melakukan pengawasan dan pengendalian atas seluruh kegiatan organisasi. Kategori tanggapan penilaian responden terhadap masing-masing item kepemimpinan terlihat pada Tabel 6. Dari Tabel 6 menujukkan jawaban responden atas indikator kepemimpinan, dimana dari 12 item yang diajukan 10 item termasuk kriteria sangat baik dan 2 item termasuk kriteria baik, dengan nilai rata-rata 4,45 atau dalam kategori sangat baik. Hal ini menunjukkan bahwa responden memiliki tanggapan yang sangat baik terhadap pemimpin dalam menjalankan fungsi-fungsi kepemimpinannya.

Tabel 6. Nilai Skor Rata-Rata dan Kategori Indikator Kepemimpinan (X1)

\begin{tabular}{|l|l|c|c|}
\hline No & \multicolumn{1}{|c|}{ Indikator } & Rata-rata & \multicolumn{1}{|c|}{ Kategori } \\
\hline 1. & Menyampaikan visi misi lembaga & 4,33 & Sangat Efektif \\
\hline 2. & Menyampaikan tujuan dan program kerja & 4,40 & Sangat Efektif \\
\hline 3. & $\begin{array}{l}\text { Membagi tugas secara adil dan tidak } \\
\text { diskriminatif }\end{array}$ & 4,35 & Sangat Efektif \\
\hline 4. & Pembagian tugas berdasrkan kompetensi & 4,46 & Sangat Efektif \\
\hline 5. & Pemberian perintah dan pengarahan yang benar & 4,61 & Sangat Efektif \\
\hline 6. & $\begin{array}{l}\text { Kejelasan dan ketegasan perintah dan } \\
\text { pengarahan }\end{array}$ & 4,63 & Sangat Efektif \\
\hline 7. & Memotivasi bawahan melalui makna kerja & 4,58 & Sangat Efektif \\
\hline 8. & Memotivasi bawahan & 4,67 & Sangat Efektif \\
\hline 9. & $\begin{array}{l}\text { Memotivasi dengan pendistribusian sumber } \\
\text { daya }\end{array}$ & 4,07 & Efektif \\
\hline 10. & Memberikan penghargaan melalui prestasi kerja & 4,33 & Efektif \\
\hline 11. & $\begin{array}{l}\text { Menyelesaikan masalah dengan adil dan } \\
\text { bijaksana }\end{array}$ & 4,58 & Sangat Efektif \\
\hline 12. & $\begin{array}{l}\text { Memberikan bimbingan dan menyelesaikan } \\
\text { masalah }\end{array}$ & 4,44 & Sangat Efektif \\
\hline & 4,45 & Sangat Efektif \\
\hline
\end{tabular}

Sumber : Data Primer Diolah.

\section{3). Beban Kerja}

Beban kerja merupakan tanggapan responden atau petugas jaga Lapas mengenai tugas yang diberikan dan yang harus diselesaikan dalam waktu yang telah ditentukan. Indikator yang digunakan adalah waktu kerja dan jumlah pekerjaan. Adapaun 
tanggapan/respon petugas jaga terhadap variabel beban kerja dapat dilihat pada Tabel 7 .

Tabel 7. Nilai Skor Rata-Rata dan Kategori Indikator Variabel Beban Kerja (X2)

\begin{tabular}{|c|l|c|c|}
\hline No & \multicolumn{1}{|c|}{ Indikator } & Rata-Rata & Kategori \\
\hline 1. & $\begin{array}{l}\text { Banyaknya waktu menyelesaikan tugas } \\
\text { penjagaan }\end{array}$ & 4,25 & Sangat Berat \\
\hline 2. & $\begin{array}{l}\text { Tingkat kesulitan/tingkat resiko dari tugas } \\
\text { penjagaan }\end{array}$ & 4,12 & Berat \\
\hline 3. & Kesesuaian waktu dengan SOP tugas penjagaan & 3,95 & Berat \\
\hline 4. & Volume pekerjaan yang dirasakan & 3,96 & Berat \\
\hline 5. & Besarnya tanggung jawab sebagai petugas jaga & 4,25 & Sangat Berat \\
\hline \multicolumn{2}{|c|}{ Rata-Rata Total } & $\mathbf{4 , 1 1}$ & Berat \\
\hline
\end{tabular}

Sumber : Data diolah (Lampiran 2)

Berdasarkan Tabel 7. memperlihatkan jawaban atas indikator beban kerja, dimana dari 5 item yang diajukan 2 item termasuk dalam kriteria sangat berat dan 3 item dalam kriteria berat, dengan nilai rata-rata 4,11 atau dalam kategori berat. Hal ini menunjukkan bahwa petugas jaga memiliki beban kerja yang berat dalam melaksanakan pekerjaan dan tanggung jawabnya.

\subsection{Analisis Statistik}

\section{1). Hasil Analisis Regresi Berganda}

Hasil analisis regresi berganda untuk meramalkan variasi komitmen organisasi jika dipengaruhi oleh kepemimpinan, beban kerja dan lingkungan kerja disajikan dalam Tabel 9.

Tabel 9. Nilai Koefisien Regresi dan Nilai Signifikansi

\begin{tabular}{|l|r|r|r|r|r|}
\hline \multirow{2}{*}{ Model } & \multicolumn{2}{|c|}{$\begin{array}{c}\text { Unstandardized } \\
\text { Coefficients }\end{array}$} & $\begin{array}{c}\text { Standardized } \\
\text { Coefficients }\end{array}$ & & \\
\cline { 2 - 4 } & \multicolumn{1}{|c|}{ B } & Std. Error & Beta & \multicolumn{1}{c|}{$\mathrm{t}$} & Sig. \\
\hline $1 \quad$ (Constant) & .931 & .557 & & 1.673 & .100 \\
Kepemimpinan & .344 & .096 & .351 & 3.579 & .001 \\
Beban Kerja & -.153 & .074 & -.196 & -2.072 & .043 \\
Lingkungan Kerja & .575 & .099 & .560 & 5.790 & .000 \\
\hline
\end{tabular}

a. Dependent Variable: Komitmen Organisasi

Sumber : Data Primer Diolah, 2017

Berdasarkan hasil analisis regresi berganda pada Tabel 9, diketahui nilai konstanta 0,931, nilai koefisien regresi variabel kepemimpinan 0,344, nilai koefisien regresi variabel beban kerja -0,153, dan nilai koefisien regresi variabel lingkungan kerja 0,575, maka persamaan regresi dihasilkan sebagai berikut:

$$
Y=0,931+0,344 X_{1}-0,153 X_{2}+0,575 X_{3}+e
$$




\section{$J M M$

Model persamaan yang diperoleh dari hasil analisis regresi berganda tersebut dapat dijelaskan sebagai berikut :

1. Nilai konstanta adalah sebesar 0,931 . Ini berarti bahwa besarnya komitmen organisasi petugas jaga adalah sebesar 0,931 dengan asumsi nilai variabel kepemimpinan, beban kerja dan lingkungan kerja adalah 0 (nol)

2. Nilai koefisien regresi variabel kepemimpinan adalah sebesar 0,344 . Ini berarti bahwa setiap perubahan yang terjadi pada variabel kepemimpinan akan menyebabkan perubahan pada variabel komitmen organisasi sebesar 0,344 dengan asumsi variabel beban kerja dan lingkungan kerja tetap. Koefisien regresi yang bertanda positif menunjukkan hubungan yang searah antara variabel kepemimpinan dengan variabel komitmen organisasi. Dengan kata lain, bahwa jika semakin baik implementasi fungsifungsi kepemimpinan Kepala Lapas, maka akan menyebabkan meningkatnya komitmen organisasi petugas jaga Lapas Klas II A Mataram, dan sebaliknya jika semakin buruk implementasi fungsi-fungsi kepemimpinan Kepala Lapas, maka akan menyebabkan menurunnya komitmen organisasi petugas jaga Lapas Klas II A Mataram.

3. Nilai koefisien regresi variabel beban kerja adalah sebesar $-0,153$. Ini berarti bahwa setiap perubahan satu satuan yang terjadi pada variabel beban kerja akan menyebabkan perubahan pada komitmen organisasi sebesar 0,153 dengan asumsi variabel kepemimpinan dan lingkungan kerja tetap. Koefisien regresi yang bertanda negatif menunjukkan hubungan yang berlawanan antara variabel beban kerja dengan variabel komitmen organisasi. Dengan kata lain, bahwa jika semakin tinggi/berat beban kerja yang dirasakan petugas jaga Lapas Klas II A Mataram, maka akan menyebabkan menurunnya komitmen organisasi mereka, dan sebaliknya jika semakin rendah/ringan beban kerja yang dirasakan petugas jaga Lapas Klas II A Mataram, maka akan menyebabkan meningkatnya komitmen organisasi mereka.

\section{2) Hasil Uji Hipotesis dengan Uji t}

Pembuktian atau pengujian hipotesis yang telah disusun dilakukan dengan menggunakan perhitungan regresi melalui bantuan program SPSS versi 17.0 for windows. Arah dan kekuatan hubungan antara variabel bebas kepemimpinan, beban kerja dan lingkungan kerja dengan variabel terikat komitmen organisasi dalam penelitian ini dapat dilihat dari nilai $t_{\text {hitung }}$ dan tingkat siginifikansinya, sebagaimana disajikan pada Tabel 9. Hasil perhitungan regresi berganda secara untuk membuktikan hipotesis yang telah disusun sebagaimana data pada Tabel 9 diatas dapat dijelaskan.

\section{(1) Pengaruh kepemimpinan terhadap komitmen organisasi}

Pengujian hipotesis dengan menggunakan tingkat keyakinan 95\%, dimana $a=5 \%$, $d f$ (degree of freedom) $=\mathrm{n}-1-\mathrm{k}=57-1-3=53$, sehingga diperoleh hasil untuk $\mathrm{t}$ tabel sebesar 2,006. Sehingga karena $t$ hitung $>t$ tabel $(3,579>2,006)$ maka dapat dinyatakan bahwa terdapat pengaruh yang signifikan dari kepemimpinan terhadap komitmen organisasi petugas jaga. Nilai signifikansi variabel kepemimpinan adalah sebesar 0,001 dimana nilai signifikansi ini lebih kecil dari nilai signifikansi yang telah ditentukan sebesar 5\% $(0,05)$, sehingga dapat disimpulkan bahwa kepemimpinan kepala Lapas Klas II A Mataram berpengaruh positif dan signifikan terhadap komitmen organisasi petugas jaga Lapas Klas II A Mataram. Hal ini berarti bahwa semakin baik implementasi fungsi-fungsi kepemimpinan oleh Kepala lapas Klas II A Mataram maka dipastikan komitmen organisasi para petugas jaga akan semakin tinggi, demikian pula sebaliknya jika semakin buruk implementasi fungsi-fungsi kepemimpinan Kepala 


\section{$J M M$ UNRAM

Lapas Klas II A Mataram maka dipastikan komitmen organisasi para petugas jaga akan semakin rendah.

(2) Pengaruh beban kerja terhadap komitmen organisasi.

Pengujian hipotesis berikutnya dengan menggunakan tingkat keyakinan 95\%, dimana $\mathrm{a}=5 \%$, df (degree of freedom) $=\mathrm{n}-1-\mathrm{k}=57-1-4=52$, sehingga diperoleh hasil untuk $\mathrm{t}$ tabel sebesar 2,006. Sehingga karena -t hitung beban kerja $<-t$ tabel $(-2,072<-2,006)$ maka dapat dinyatakan bahwa terdapat pengaruh yang signifikan dari beban kerja terhadap komitmen organisasi petugas jaga. Nilai signifikansi variabel beban kerja adalah 0,043 dimana nilai signifikansinya ini lebih kecil dari nilai signifikansi yang telah ditentukan sebesar 5\% $(0,05)$, sehingga dapat disimpulkan bahwa beban kerja berpengaruh negatif dan signifikan terhadap komitmen organisasi petugas jaga Lapas Klas II A Mataram. Hal ini berarti jika beban kerja yang dirasakan petugas jaga semakin berat, maka dipastikan komitmen organisasi para petugas jaga akan menjadi semakin rendah, demikian pula sebaliknya jika beban kerja yang dirasakan petugas jaga semakin ringan, maka dipastikan komitmen organisasi yang dirasakan petugas jaga akan semakin tinggi.

(3) Pengaruh lingkungan kerja terhadap komitmen organisasi.

Pengujian hipotesis ketiga dengan menggunakan tingkat keyakinan 95\%, dimana $a=5 \%$, df (degree of freedom) $=n-1-k=57-1-4=52$, sehingga diperoleh hasil untuk $t$ tabel sebesar 2,006. Sehingga karena $t$ hitung lingkungan kerja $>t$ tabel $(5,790>2,006)$ maka dapat dinyatakan bahwa terdapat pengaruh yang signifikan dari lingkungan kerja terhadap komitmen organisasi petugas jaga. Nilai signifikansi variabel lingkungan kerja adalah 0,000 dimana nilai signifikansinya ini lebih kecil dari nilai signifikansi yang telah ditentukan sebesar 5\% (0,05), sehingga dapat disimpulkan bahwa lingkungan kerja berpengaruh positif dan signifikan terhadap komitmen organisasi petugas jaga Lapas Klas II A Mataram.

\section{3). Uji Koefisien Determinasi $\left(\mathbf{R}^{2}\right)$}

Koefisien determinasi $\left(\mathrm{R}^{2}\right)$ pada intinya mengukur seberapa jauh kemampuan model dalam menerangkan variasi variabel terikat (Kuncoro, 2007 :84). Uji determinasi (agregat, $\mathrm{R}^{2}$ ) adalah uji kemampuan seluruh variabel $\mathrm{X}$ menjelaskan perilaku variabel $\mathrm{Y}$ (Adisoewignyho, 2008:277). Hasil perhitungan koefisien determinasi $\left(R^{2}\right)$ variabel kepemimpinan, beban kerja, dan lingkungan kerja terhadap komitmen organisasi dalam penelitian ini disajikan pada Tabel 10

Tabel 10. Hasil Uji Koefisien Determinasi $\left(\mathbf{R}^{2}\right)$

Model Summaryb

\begin{tabular}{|c|c|c|c|c|c|c|c|c|c|c|}
\hline \multirow[b]{2}{*}{ Model } & \multirow[b]{2}{*}{$\mathrm{R}$} & \multirow[b]{2}{*}{$\begin{array}{c}\mathrm{R} \\
\text { Square }\end{array}$} & \multirow[b]{2}{*}{$\begin{array}{l}\text { Adjusted } \\
\text { R Square }\end{array}$} & \multirow{2}{*}{$\begin{array}{c}\text { Std. } \\
\text { Error of } \\
\text { the } \\
\text { Estimate }\end{array}$} & \multicolumn{5}{|c|}{ Change Statistics } & \multirow[b]{2}{*}{$\begin{array}{l}\text { Durbin- } \\
\text { Watson }\end{array}$} \\
\hline & & & & & $\begin{array}{l}\text { R Square } \\
\text { Change }\end{array}$ & $\begin{array}{c}\mathrm{F} \\
\text { Change }\end{array}$ & df1 & df2 & $\begin{array}{c}\text { Sig. F } \\
\text { Change }\end{array}$ & \\
\hline 1 & $.737 a$ & .543 & .518 & .25430 & .543 & 21.030 & 3 & 53 & .000 & 1.558 \\
\hline
\end{tabular}

a. Predictors: (Constant), Lingkungan Kerja, Beban Kerja, Kepemimpinan

b. Dependent Variable: Komitmen Organisasi 


\section{$J M M$

Sumber : Data primer diolah, 2017

Pada tabel 10 terlihat bahwa nilai Adjusted $R$ Square (koefisien determinasi) sebesar 0,518 (51,8\%). Ini berarti bahwa pengaruh ketiga variabel bebas yakni kepemimpinan (X1), Beban Kerja (X2), Lingkungan kerja (X3) terhadap variabel terikat yakni Komitmen Organisasi $(Y)$ adalah sebesar 51,8\%, sedangkan 48,2\% (100\% - 51,8\%) dipengaruhi oleh variabel lain diluar model ini. Beberapa variabel lainnya yang mempengaruhi komitmen organisasi yakni motivasi, etika kerja, kompetensi, kompensasi, kepuasan kerja, karakteristik pekerjaan, usia, tingkat pendidikan, dll.

\subsection{Pembahasan Hasil Penelitian}

1). Pengaruh Kepemimpinan Terhadap Komitmen Organisasi Petugas Jaga Lapas Klas II A Mataram

Berdasarkan hasil analisis diketahui bahwa kepemimpinan berpengaruh positif dan signifikan terhadap komitmen organisasi petugas jaga Lapas Klas II A Mataram, sehingga hipotesis 1 yang menyatakan "Diduga kepemimpinan berpengaruh positif dan signifikan terhadap komitmen organisasi petugas jaga Lapas Klas II A Mataram" diterima.

Hasil penelitian ini sesuai pendapat Subanegara (2005), "kepemimpinan merupakan salah satu faktor yang dapat mempengaruhi komitmen organisasi". Selain itu Pillai dan Williams dalam Indrayanto,dkk (2011:258), bahwa "komitmen dapat terbentuk dari adanya kepercayaan yang kuat pada diri bawahan terhadapa atasannya". Hasil penelitian ini sama dengan beberapa penelitian terdahulu yaitu Zuraida, dkk (2013), Koesmono (2007), Raharjo dan Nafisah (2006), Yunita Sari, dkk (2017), Wirapranaya dan Supharta (2016), Novita Mamahit (2016), Lalu Suparman, dkk (2015 dan 2016) dimana hasil penelitiannya menunjukkan bahwa kepemimpinan berpengaruh positif dan signifikan terhadap komitmen organisasi.

\section{2) Pengaruh Beban Kerja Terhadap Komitmen Organisasi Petugas Jaga Lapas Klas II A Mataram}

Berdasarkan hasil analisis diketahui bahwa beban kerja berpengaruh negatif dan signifikan terhadap komitmen organisasi petugas jaga Lapas Klas II A Mataram, sehingga hipotesis 2 yang menyatakan "Diduga beban kerja berpengaruh negatif dan signifikan terhadap komitmen organisasi petugas jaga Lapas Klas II A Mataram" diterima.

Berdasarkan pendapat yang disampaikan oleh Rivai (2003: 50-53) pada fungsi instruktif kepemimpinan, pemimpin menentukan dan memutuskan apa, bagaimana, bilamana, dimana tugas/pekerjaan dilaksanakan dan menentukan siapa bawahan/pengikut yang melaksanakan tugas tersebut. Hal ini menggambarkan tentang pemberian beban kerja kepada bawahan dalam mendorong keterlibatannya di dalam organisasi. Schultz (Suwatno, 2011 :250) bahwa beban kerja ditempat kerja bukan saja menyangkut kelebihan pekerjaan (work overload) tetapi termasuk pula yang setara/sama atau sebaliknya kekurangan atau terlalu rendah/kecil pekerjaan (work underload)

\section{3) Pengaruh Lingkungan Kerja Terhadap Komitmen Organisasi Petugas Jaga Lapas Klas II A Mataram}

Berdasarkan hasil analisis diketahui bahwa lingkungan kerja berpengaruh positif dan signifikan terhadap komitmen organisasi petugas jaga Lapas Klas II A Mataram, sehingga hipotesis 3 yang menyatakan "Diduga lingkungan kerja berpengaruh positif dan signifikan terhadap komitmen organisasi petugas jaga Lapas Klas II A Mataram" diterima. 


\section{$J M M$

Hasil analisis ini memberikan gambaran bahwa semakin baik lingkungan kerja Lapas Klas II A Mataram, maka akan dapat meningkatkan komitmen organisasi petugas jaga. Lingkungan kerja ini meliputi pelayanan kerja, kondisi kerja, dan hubungan karyawan.

\subsection{Kesimpulan}

\section{KESIMPULAN}

1). Berdasarkan hasil pembahasan variabel secara deskriptif, bahwa komitmen organisasi dari para petugas jaga Lapas Klas II A Mataram menunjukkan sangat tinggi. Hal ini didukung oleh kepemimpinan Kepala Lapas Klas II A Mataram yang telah dipersepsikan oleh para petugas jaga termasuk dalam kategori sangat baik. Beban kerja yang dirasakan petugas jaga Lapas Klas II A Mataram termasuk dalam kategori berat. Hal tersebut tidak menurunkan komitmen mereka karena pekerjaan yang menantang bisa membuat mereka makin komitmen dalam bekerja. Lingkungan kerja yang dirasakan petugas jaga Lapas Klas II A Mataram termasuk dalam kategori sangat baik, telah menjadikan petugas jaga memiliki komitmen organisasi yang sangat tinggi.

2). Berdasarkan hasil analisis statistik dengan regresi berganda menggunakan bantuan softwere SPSS versi 17.0, dapat ditarik kesimpulan sebagai berikut :

(1) Kepemimpinan memiliki pengaruh yang positif dan sigifikan terhadap komitmen organisasi, artinya semakin baik implementasi fungsi-fungsi kepemimpinan oleh Kepala Lapas Klas II A Mataram maka dipastikan komitmen organisasi para petugas jaga akan semakin tinggi dan sebaliknya semakin buruk implementasi fungsi-fungsi kepemimpinan oleh Kepala Lapas Klas II A Mataram maka dipastikan komitmen organisasi para petugas jaga akan semakin rendah.

(2) Beban kerja memiliki pengaruh negatif dan signifikan terhadap komitmen organisasi, artinya bahwa jika beban kerja yang dirasakan petugas jaga semakin berat, maka dipastikan komitmen organisasi para petugas jaga akan menjadi semakin rendah, dan sebaliknya jika beban kerja yang dirasakan petugas jaga semakin ringan, maka dipastikan komitmen organisasi para petugas jaga akan menjadi semakin tinggi.

\section{DAFTAR PUSTAKA}

Amstrong, Michael, (1992), A Handbook of Personel Management Practice, London : Kogan Page

Antonio, Muhammad Syafii, (2007), Muhammad SAW The Super Leader Super Manager, Jakarta : Tazkia Multimedia \& ProLM Centre

Arifin M.Z, Alhabsji T., Utami H.N., (2016), "Pengaruh Beban Kerja Dan Kompensasi Terhadap Komitmen Organisasional Dalam Upaya Meningkatkan Kinerja Karyawan (Studi Pada Karyawan Tingkat Pelaksana Jasa Tirta I Wilayah Sungai Brantas dan Bengawan Solo)", Jurnal Bisnis dan Manajemen, vol.3(2) : 64-76

Brown, L. K., Dan Bennet, V. R., (2003), Miles Textbook of Midwives. Toronto : Churchill Livingstone

Buchari Alrad, (2001), Manajemen Pemasaran dan Pemasaran Jasa, Bandung : CV. Alfabeta

Dubrin, A.J., (2001), Leadership : Research Findings, Practice, and Skill, Third Edition, Boston: houghton Mifflin Company

Dubrin Andrew J., (2005), Leadership (Terjemahan), Edisi Kedua, Prenada Media, Jakarta

Ghoniyah N., Masurip, (2011), “Peningkatan Kinerja Karyawan Melalui Kepemimpinan, Lingkungan Kerja dan Komitmen", Jurnal Dinamika Manajemen, vol.2 (2) : 118-129 


\section{$J M M$

Gibson, J. L., Ivancevich, J. M., dan Donnelly, J. H., (2008), Organisasi, Perilaku, Struktur, dan Proses, Jakarta : Binapura Aksara Publisher

Hanaysha J., (2016), “Testing the Effect of Employee Engangement, Work Environment, and Organizational Learning on Organizational Commitment". Procedia-Social and Behavioral Sciencesong, vol. 229 (2016) : 289-297

Hauck, Erica L, dan Snyder, Lori Anderson., 2008, “Workload and Variability and Social Support : Effect On Stress and Performance", Springer Science + Business Media, vol.27 (1) : 112-125.

Hartanto, Produktivitas Perusahaan, (2000), Jakarta : Edisi Pertama, Rajawali Press.

Husain, N., (2015), Pengaruh Lingkungan Kerja dan Beban Kerja Terhadap Motivasi Kerja Anggota Satuan Brimob Polisi daerah Nusa Tenggara Barat: Tesis Program Magister Manajemen Pascasarjana Universitas Mataram

Indrayanto, A., Troena, E.A., Surachman, dan Noermijati., (2011), "Efek Pemediasian Kepercayaan Terhadap Pengaruh Kepemimpinan Transformasional pada Komitmen Pegawai Satpol-PP di Eks Karasidenan Banyumas", Jurnal Aplikasi manajemen, 10 (2):252-261

Ivancevich, J. M., Robert, K., Michel T. M., (2006), Perilaku dan Manajemen Organisasi, Jilid 1, Jakarta : Penerbit Erlangga

Kartono, Kartini, (2005), Kepemimpinan : Apakah Kepemimpinan Abnormal itu?, Jakarta : PT. Raja Graffindo Persada

Koesmono H Teman, (2007), “Pengaruh Kepemimpinan dan Tuntutan Tugas Terhadap Komitmen Organisasi Dengan Variabel Moderasi Motivasi Perawat Rumah sakit Swasta Surabaya", Jurnal Manajemen dan Kewirausahaan, vol.9 (1) : 30-40

Suparman Lalu, Mahyudin Nasir, Sarufudin Serif (2015), “Analisis Pengaruh Kepemimpinan Terhadap Kepuasan Kerja, Komitmen Organisasi dan Perilaku Kerja Bawahan (Studi pada Fakultas di Lingkungan Universitas Swasta di Kota Mataram)" : Laporan Penelitian Lembaga Penelitian Universitas Mataram

Luthans, Fred, (2006), "Perilaku Organisasi", Edisi Sepuluh, Yogyakarta : Penerbit ANDI

Mahmudi, (2007), Manajemen Kinerja Sektor Publik, YPKN Yogyakarta : Unit Penerbit dan Pencetakan Sekolah Tinggi Ilmu Manjemen

Mangkunegara, A.P, (2009), Manajemen Sumber Daya Manusia Perusahaan, Bandung : Cetakan Ketiga, PT. Remaja Rosdakarya

Mas'ud, F., (2004), "Survei Diagnosis Organisasional, Konsep dan Aplikasi", Program Magister Manajemen Universitas Diponegoro, Semarang : UNDIP

Miner, J. B, (1992), Industrial-Organizational Psychology, United States of America : McGrawHill

Moekijat, (2002), Manajemen Sumber daya Manusia : Manajemen Kepegawaian, Jakarta : Mandar Maju

Nitisemito Alex S, (1996), Manajemen Personalia, Jakarta : Ghalia Indonesia

Nawawi, Hadari, (2001), Kepemimpinan Menurut Islam, Yogyakarta : Gajah Mada University Press

Northouse, P.G., (2003), Leadership : Theory and Practice, Third Edition,. New Delhi : Response Book

Raharjo Susilo T, Nafisah D., (2006), “Analisis Pengaruh gaya Kepemimpinan Terhadap Kepuasan Kerja, Komitmen Organisasi, Dan Kinerja Karyawan (Studi Empiris Pada Depag Kab.Kendal dan Kota Semarang)", Jurnal Studi Manajemen dan Organisasi, vol.3 (2) : 69-81

Rivai, Veithzal, (2003), Kepemimpinan dan Perilaku Organisasi, Jakarta : PT. Aja Grafindo 


\section{$J M M$

Perada

Robbins, Stephen P, (2006), Teori Organisasi : Struktur, Desain dan Aplikasi, Jakarta : Arcan Robbins, S.P. \& Judge, A. T, (2008), Perilaku Organisasi, (edisi keduabelas), Terjemahan, Angelca, Jakarta : Salemba Empat

Steers, R. M and Porter, R. W, (1983), Motivation and Work Behavior, New York : Mc Graw Hill

Subanegara, H.P., (2005), Diamond head drill dan kepemimpinan dalam manajemen rumah sakit, Yogyakarta : Penerbit ANDI 